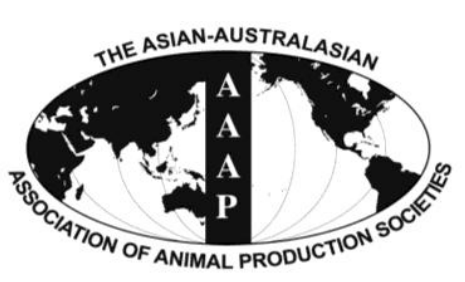

\begin{tabular}{c} 
Open Access \\
Asian Australas. J. Anim. Sci. \\
Vol. 27, No. 1 : 69-76 January 2014 \\
http://dx.doi.org/10.5713/ajas.2012.12585 \\
\hline www.ajas.info \\
pISSN 101 1-2367 elSSN 1976-5517
\end{tabular}

\title{
Effects of Dietary Levels of Glycine, Threonine and Protein on Threonine Efficiency and Threonine Dehydrogenase Activity in Hepatic Mitochondria of Chicks
}

\author{
C. W. Lee ${ }^{1, a}$, I. J. Cho ${ }^{2, a}$, Y. J. Lee', Y. S. Son ${ }^{3}$, I. Kwak ${ }^{4}$, Y. T. Ahn' ${ }^{1}$, S. C. Kim²,*, and W. G. An ${ }^{1,5, *}$ \\ ${ }^{1}$ Institute of Marine BioTechnology, Pusan National University, Busan, 609-735, Korea
}

\begin{abstract}
This study was carried out to evaluate the relationship between threonine (Thr) efficiency and Thr dehydrogenase (TDG) activity as an indicator of Thr oxidation on chicks fed with levels of diets (CP [17.5\% and 21.5\%] and Thr [3.8 and $4.7 \mathrm{~g} / 100 \mathrm{~g}$ CP]; glycine [Gly][0.64\% and 0.98\%] and true digestible Thr [dThr] [0.45\% and 0.60\%]). Calculation of the Thr efficiency was based on N-balance data and an exponential N-utilization model, and TDG activity was determined as accumulation of aminoacetone and Gly during incubation of hepatic mitochondria. This study found that in the liver of chicks who received a diet containing up to $0.79 \%$ Thr $(4.7 \mathrm{~g} \mathrm{Thr} / 100 \mathrm{~g}$ of $\mathrm{CP})$ in the $17.5 \% \mathrm{CP}$ diet, no significant $(\mathrm{p}>0.05)$ effect on TDG activity was observed. However, significantly $(\mathrm{p}=$ 0.014) increased TDG activity was observed with a diet containing $21.5 \% \mathrm{CP}(4.7 \mathrm{~g} \mathrm{Thr} / 100 \mathrm{~g} \mathrm{of} \mathrm{CP})$ and the efficiency of Thr utilization showed a significant $(\mathrm{p}=0.001)$ decrease, indicating the end of the Thr limiting range. No significant $(\mathrm{p}>0.05)$ effect on the total TDG activity and accumulation of Gly was observed with addition of Gly to a diet containing $0.45 \%$ dThr. In addition, addition of Gly to a diet containing $0.60 \% \mathrm{dThr}$ also did not result in a change in accumulation of Gly. Due to an increase in accumulation of aminoacetone, an elevated effect on total TDG activity was also observed. No significant ( $>0.05)$ reduction in the efficiency of Thr utilization was observed after addition of Gly at the level of $0.45 \%$ dThr. However, significantly $(\mathrm{p}<0.001)$ reduced efficiency of Thr utilization was observed after addition of Gly at the level of $0.60 \%$ dThr. Collectively, we found that TDG was stimulated not only by addition of Thr and protein to the diet, but also by addition of Gly, and efficiency of Thr utilization was favorably affected by addition of Gly at the level near to the optimal Thr concentration. In addition, no metabolic requirement of Gly through the TDG pathway was observed with almost the same accumulation of Gly and a slight increase in TDG activity by addition of Gly. Thus, our findings suggest that determination of TDG activity and parameter of efficiency of Thr utilization may be useful for evaluation of dietary Thr level. (Key Words: Addition of Glycine and Threonine, Liver of Chick, Threonine Dehydrogenase, Threonine Efficiency)
\end{abstract}

\section{INTRODUCTION}

Gly is classified as a non-essential amino acid for birds

\footnotetext{
* Corresponding Authors: W. G. An. Tel: +82-51-510-8455, Fax: +82-51-510-8447, E-mail: wgan@pusan.ac.kr / S. C. Kim. Tel: +82-53-819-1863, Fax: +82-53-819-1863, E-mail: sckim@ dhu.ac.kr

2 College of Korean Medicine, Daegu Haany University, Gyeongsan 712-715, Korea.

3 Division of Life Sciences, College of Life Sciences and Biotechnology, Korea University, Seoul, 136-701, Korea.

${ }^{4}$ Department of Biological Sciences, Silla University, Busan, 617-736, Korea.

${ }^{5}$ Division of Pharmacology, School of Korean Medicine, Pusan National University, Yangsan, 626-870, Korea.

${ }^{a}$ These authors contributed equally to this work.

Submitted Oct. 20, 2012; Accepted Dec. 26, 2012; Revised Sept. 26, 2013
}

and mammals. However, it has been suggested as an essential amino acid for maximum performance of growing chicks (Corzo et al., 2004; Waguespack, 2005; Waldroup et al., 2005; Dean et al., 2006). In addition, Gly has the following metabolic functions: synthesis of proteins, purines, porphyrin moiety of heme groups (Furuya, 2008), glutathione (te Braake et al., 2008), creatine (Wyss and Kaddurah-Daouk, 2000), and hippuric acid (Asai et al., 1995). Gly has also been reported as indispensable for synthesis of uric acid for excretion of any excess nitrogen (Corzo et al., 2004). Thus, Gly is of significant importance in amino acid metabolism of growing chicks (Schutte et al., 1997). In addition, serine (Ser) also plays an important role in growing chicks, because Gly is biosynthesized from the amino acid Ser by Ser hydroxymethyl transferase. In 
particular, there is an interconversion between Gly and Ser (Osanai and Okudaira, 2001; Lamers et al., 2007). Therefore, a sum of Gly and Ser for evaluation of the adequacy of supply is important in poultry nutrition (NRC, 1994; Corzo et al., 2009).

Thr is an essential amino acid for birds and mammals (Baylan et al., 2006; Ayaşan et al., 2009). Thr degradation occurs in the liver, mainly via two major pathways (Davis and Austic, 1994) based on the enzymes Thr dehydratase (TDH, EC 4.2.1.16) and Thr dehydrogenase (TDG, EC 1.1.1.103). TDG is a mitochondrial enzyme, yielding Gly and aminoacetone (Davis and Austic, 1997; Yuan and Austic, 2001; Sartori et al., 2008). Thr catabolism through TDG is also an important pathway of Thr oxidation. As a result, Gly is formed from Thr (Davis and Austic, 1997; Lee et al., 2011). The de novo synthesis of Gly from Thr might partly cover the metabolic requirements for Gly through the TDG pathway (Le Floc'h et al., 1994).

The purpose of the current study was to investigate the effects of a diet supplemented with different levels of Gly, Thr, and protein on Thr efficiency and to monitor its relationship with TDG activity as an indicator for $\mathrm{Thr}$ degradation rate in growing chicks.

\section{MATERIALS AND METHODS}

\section{Material}

L-Thr and NAD were purchased from Merck and CoA was obtained from Sigma. Other chemicals obtained from commercial suppliers were of analytical reagent grade or the highest purity available.

\section{Animals and experiments}

D-old male chicks (Cobb 500) were prepared for the experiments and fed a commercial starter diet up to the beginning of the trial period. A total of 24 chicks from each experiment were used in N-balance study according to age period (Experiment I: 10 to $20 \mathrm{~d}$; Experiment II: 5 to $15 \mathrm{~d}$ ). For each N-balance study, 24 chicks were randomly allocated to four diets with a graded supply of Thr and protein (Tables 3, 4, and 7) or Gly and dThr (Tables 5, 6, and 8). Chicks were individually housed in metabolism cages with wire floors equipped with individual feeding and self-drinking systems. Initial average BWs within the age period were $279 \pm 31$ and $118 \pm 16 \mathrm{~g}$ for experiment I and II, respectively. Each $\mathrm{N}$-balance study within the age period used 6 chicks per diet. The individual experimental period was divided into an adaptation period $(5 \mathrm{~d})$ and consecutive excreta collecting period $(5 \mathrm{~d})$. This experiment was conducted using the procedures of Samadi and Liebert (2006).

After the N-balance study, these chicks were sacrificed for sampling of individual livers. Room temperature during rearing started at $32^{\circ} \mathrm{C}$ for optimal growth in the first wk after hatching and declined by $2^{\circ} \mathrm{C}$ per wk, lighting was 24 $h$ per $d$. Both N-balance studies should provide experimental data regarding the efficiency of Thr utilization in Thr limiting basal diets as well as the effects of graded levels of Gly and Thr supplementation on protein deposition. All animal procedures and handlings were conducted in accordance with animal welfare legislation and were approved by the ethics committee of Pusan National University.

\section{Diets}

The chick diets contained a mixture of soybean meal (44\% CP) (Experiment I, Table 3) and wheat and wheat gluten (Experiment II, Table 5). Diets were supplemented with amino acids for achievement of an amino acid composition of the protein fraction according to ideal protein (Baker and Han, 1994), with the exception of Thr as a limiting amino acid. Crystalline Thr (L-Thr) was only supplemented to make diets with an equal Thr supply but a different protein concentration. Diets for chicks were supplied to meet the recommendations of NRC (1994), except for Thr.

In the dietary requirement for Gly+Ser, Schutte et al. (1997) reported that the requirement for Gly+Ser was estimated to be between 1.8 to $1.9 \%$. In addition, Corzo et al. (2004) suggested that the Gly+Ser requirement is $1.80 \%$ in a low-CP, all-vegetable, corn and soybean meal diet. Waguespack et al. (2009) also reported that the total Gly+ Ser minimum requirement was estimated to be $2.10 \%$ in a low-CP, corn and soybean meal based diet (0 to $18 \mathrm{~d}$ old broilers). However, the NRC (1994) recommendations are $1.25 \% \mathrm{Gly}+\mathrm{Ser}$ and $0.80 \% \mathrm{Thr}(23 \% \mathrm{CP}$ diet $)$ for chicks $(0$ to $3 \mathrm{wk}$ of age). Based on these data, in experiment I, we examined two levels of Thr ([3.8 $\mathrm{g}$ Thr/100 $\mathrm{g}$ of CP] and [4.7 $\mathrm{g} \mathrm{Thr} / 100 \mathrm{~g}$ of $\mathrm{CP}])$ in $\mathrm{CP}$ diets $(17.5 \%$ and $21.5 \%)$. In addition, two levels of Gly+Ser $(1.55 \%$ and $1.90 \%)$ and dThr $(0.45 \%$ and $0.60 \%)$ in $21.5 \% \mathrm{CP}$ diets were also examined in experiment II.

\section{Preparation of liver extracts}

The individual livers of six animals per treatment were collected. After preparation, the livers were immediately frozen in liquid nitrogen and kept at $-80^{\circ} \mathrm{C}$ before homogenization in ice-cold $0.25 \mathrm{M}$ sucrose solution. The liver mitochondria fraction was isolated from the homogenate and sediments of the mitochondria fraction

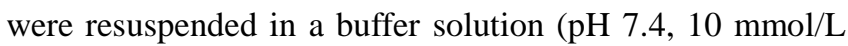
Tris- $\mathrm{HCl}, 10 \mathrm{mmol} / \mathrm{L} \mathrm{KH}_{2} \mathrm{PO}_{4}, 110 \mathrm{mmol} / \mathrm{L} \mathrm{KHCO}_{3}$, and 5 $\mathrm{mmol} / \mathrm{L} \mathrm{MgCl}_{2} \cdot 6 \mathrm{H}_{2} \mathrm{O}$ ).

\section{Threonine dehydrogenase assay}

The mitochondrial solution $(0.5 \mathrm{~mL})$ was incubated in a 
metabolic shaker bath for $30 \mathrm{~min}\left(0 \mathrm{~min}\right.$ for blanks) at $37^{\circ} \mathrm{C}$ in stoppered test tubes for culture with $2 \mathrm{~mL}$ of a modified medium (pH 7.4, $10 \mathrm{mmol} / \mathrm{L}$ Tris- $\mathrm{HCl}, 10 \mathrm{mmol} / \mathrm{L} \mathrm{KH}_{2} \mathrm{PO}_{4}$, $110 \mathrm{mmol} / \mathrm{L} \mathrm{KHCO}_{3}, 5 \mathrm{mmol} / \mathrm{L} \mathrm{MgCl}_{2} \cdot 6 \mathrm{H}_{2} \mathrm{O}, 25 \mathrm{mmol} / \mathrm{L}$ L- Thr, $2.5 \mathrm{mmol} / \mathrm{L} \mathrm{NAD,} \mathrm{and} 1 \mathrm{mmol} / \mathrm{L} \mathrm{CoA}$ ) using the method described by Davis and Austic (1997). After incubation, the reaction was terminated with $1 \mathrm{~mL}$ of trichloracetic acid $(0.92 \mathrm{~mol} / \mathrm{L})$. The precipitated protein was removed by centrifugation at $4{ }^{\circ} \mathrm{C}$ and the supernatant was used for the assay of aminoacetone and Gly. Aminoacetone was determined using the rapid colorimetric method and Gly was detected by column chromatography in an automatic amino acid analyzer LC 3000 (Biotronik). The Biuret-assay with bovine serum albumin standards was used for measurement of protein concentration.

\section{N-utilization model and evaluation of threonine efficiency}

Calculation of the efficiency of Thr was based on Nbalance data and an exponential $\mathrm{N}$-utilization model (Samadi and Liebert, 2006), which was adapted to describe the relationship between concentration of the limiting amino acid (LAA) (c) and protein quality (b). The slope of the linear function $\left(\mathrm{bc}^{-1}\right)$ is used directly as an indicator for the efficiency of the utilization of the limiting amino acid in the diet (Liebert, 1995; Rimbach and Liebert, 2000; Thong and Liebert, 2004).

Principles of an exponential N-utilization model (Liebert, 1995; Thong and Liebert, 2004; Samadi and Liebert, 2006) were applied for analysis of the N-balance data:

$$
\mathrm{NR}=\mathrm{NR}_{\max } \mathrm{T}\left(1-\mathrm{e}^{-\mathrm{b} \cdot \mathrm{NI}}\right)
$$

Where, $\mathrm{NR}=$ daily $\mathrm{N}$ retention $\left(\mathrm{mg} / \mathrm{BW}_{\mathrm{kg}}{ }^{0.67}\right) ; \mathrm{NR}_{\max } \mathrm{T}$ $=$ theoretical maximum for daily $\mathrm{N}$ retention $\left(\mathrm{mg} / \mathrm{BW}_{\mathrm{kg}}{ }^{0.67}\right)$; $\mathrm{NI}=$ daily $\mathrm{N}$ intake $\left(\mathrm{mg} / \mathrm{BW}_{\mathrm{kg}}{ }^{0.67}\right) ; \mathrm{b}=$ model parameter for the slope of the function between NI and NR, depending on the dietary protein quality; e = basic number of natural logarithm.

Modeling of amino acid requirements may run for graded dietary amino acid efficiency within the variation of observed efficiency of amino acid utilization. Due to logarithmization and transformation of equation (1), equation (2) was applied for establishment of a model parameter from $\mathrm{N}$-balance studies with a graded protein supply (Samadi and Liebert, 2006).

$$
\mathrm{b}=\ln \left[\mathrm{NR}_{\max } \mathrm{T}-\ln \left(\mathrm{NR}_{\max } \mathrm{T}-\mathrm{NR}\right)\right] / \mathrm{NI}
$$

Where $\mathrm{b}=$ model parameter of dietary protein quality; ln = natural logarithm; $\mathrm{NR}_{\max } \mathrm{T}=$ theoretical maximum for daily $\mathrm{N}$ retention $\left(\mathrm{mg} / \mathrm{BW}_{\mathrm{kg}}^{0.67}\right) ; \mathrm{NR}=$ daily $\mathrm{N}$ retention $\left(\mathrm{mg} / \mathrm{BW}_{\mathrm{kg}}{ }^{0.67}\right) ; \mathrm{NI}=$ daily $\mathrm{N}$ intake $\left(\mathrm{mg} / \mathrm{BW}_{\mathrm{kg}}{ }^{0.67}\right)$.

In general, the concentration of the LAA in the feed protein and the resulting dietary protein quality are linearly correlated. The slope of the linear function (quotient $\mathrm{bc}^{-1}$ ) indicates the efficiency of utilization of the LAA in the diet (Liebert, 1995). In addition, parameter $\left(\mathrm{bc}^{-1}\right)$ summarizes the efficiency within the processes of digestion and absorption and postabsorptive utilization. Calculation of the efficiency of Thr utilization $\left(\mathrm{bc}^{-1}\right)$ is based on the analyzed Thr concentration $\left(\mathrm{bc}^{-1}=\right.$ slope between $\mathrm{b}$ and $\mathrm{c} ; \mathrm{b}=$ model parameter of dietary protein quality; $\mathrm{c}=$ concentration of the LAA in the feed protein $[\mathrm{g} / 100 \mathrm{~g}$ of $\mathrm{CP}]$ ).

\section{Statistical analysis}

Statistical analysis was carried out using SPSS Base 14.0 (SPSS Software products, Marketing Department, SPSS Inc. Chicago, IL 60606-6307, USA). Data were subjected to two-way ANOVA and the statistical model included the main effects (CP and Thr; Gly and dThr) and interaction between them. Difference between the levels of groups was separated using Independent-samples $\mathrm{T}$ test. Differences were considered significant at $p<0.05$. The data are expressed as mean $\pm \mathrm{SD}$.

\section{RESULTS}

\section{Experiment 1}

A summary of data from $\mathrm{N}$-balance experiments with chicks is shown in Table 1 . Results with growing chicks (Table 7) at a CP level of $17.5 \%$ (a lower CP level) showed that the total TDG activity did not respond directly to dietary supplementation with Thr. However, addition of Thr to the diet containing a higher $\mathrm{CP}$ level $(21.5 \% \mathrm{CP})$ resulted in a significant $(\mathrm{p}=0.014)$ increase in TDG activity. This result was due to an increase in aminoacetone and Gly

\begin{tabular}{|c|c|c|c|c|c|c|c|c|c|c|c|c|}
\hline \multirow{2}{*}{ Thr } & \multicolumn{4}{|c|}{ Mean BW } & \multicolumn{4}{|c|}{ Feed intake } & \multicolumn{4}{|c|}{$\mathrm{N}$ retention ${ }^{1}$} \\
\hline & $17.5 \% \mathrm{CP}$ & $21.5 \% \mathrm{CP}$ & Avg. & p-value & $17.5 \% \mathrm{CP}$ & $21.5 \% \mathrm{CP}$ & Avg. & p-value & $17.5 \% \mathrm{CP}$ & $21.5 \% \mathrm{CP}$ & Avg. & $\mathrm{p}$-value \\
\hline $3.8 \mathrm{~g} / 100 \mathrm{~g} \mathrm{CP}$ & $435^{\mathrm{a}} \pm 32$ & $455^{\mathrm{a}} \pm 35$ & $445 \pm 34$ & \multirow{3}{*}{0.004} & $41.9^{\mathrm{a}} \pm 3.3$ & $44.3^{\mathrm{a}} \pm 3.5$ & $43.1 \pm 3.5$ & \multirow{3}{*}{0.080} & $1,449^{\mathrm{a}} \pm 31$ & $1,733^{\mathrm{c}} \pm 37$ & $1,591 \pm 152$ & \multirow{3}{*}{$<0.001$} \\
\hline $4.7 \mathrm{~g} / 100 \mathrm{~g} \mathrm{CP}$ & $452^{\mathrm{a}} \pm 15$ & $510^{\mathrm{b}} \pm 23$ & $481 \pm 35$ & & $43.2^{\mathrm{a}} \pm 3.2$ & $48.6^{\mathrm{b}} \pm 4.7$ & $45.9 \pm 4.8$ & & $1,567^{b} \pm 38$ & $2,056^{\mathrm{d}} \pm 50$ & $1,811 \pm 259$ & \\
\hline Avg. & $444 \pm 25$ & $483 \pm 40$ & $463 \pm 38$ & & $42.6 \pm 3.2$ & $46.5 \pm 4.5$ & $44.5 \pm 4.3$ & & $1,507.7 \pm 70.0$ & $1,894.3 \pm 174.0$ & $1,701 \pm 236$ & \\
\hline$p$-value & \multicolumn{2}{|c|}{0.002} & & $0.108^{*}$ & \multicolumn{2}{|c|}{0.018} & & $0.340 *$ & \multicolumn{2}{|c|}{$<0.001$} & & $<0.001^{*}$ \\
\hline
\end{tabular}

Table 1. Summarized data from N-balance experiments $(n=6)$ with chicks (genotype Cobb 500) in age period (10 to $20 \mathrm{~d})$

Values indicate mean $\pm \mathrm{SD}(\mathrm{n}=6) .{ }^{1} \mathrm{mg} / \mathrm{BW}_{\mathrm{kg}}{ }^{0.67}$ per $\mathrm{d}$.

${ }_{a, b, c, d}$ Different superscripts within a row indicate significant differences $(\mathrm{p}<0.05 ; t$-test $)$

* p-value of interaction effect. 
Table 2. Summarized data from N-balance experiments $(n=6)$ with chicks (genotype Cobb 500) fed with a crude protein level of $21.5 \%$ in age period ( 5 to $15 \mathrm{~d})$

\begin{tabular}{|c|c|c|c|c|c|c|c|c|c|c|c|c|}
\hline \multirow{2}{*}{$\mathrm{dThr}^{1}$} & \multicolumn{4}{|c|}{ Mean BW } & \multicolumn{4}{|c|}{ Feed intake } & \multicolumn{4}{|c|}{$\mathrm{N}$ retention ${ }^{2}$} \\
\hline & $0.64 \%$ Gly & $0.98 \%$ Gly & Avg. & $\mathrm{p}$-value & $0.64 \%$ Gly & $0.98 \%$ Gly & Avg. & p-value & $0.64 \%$ Gly & $0.98 \%$ Gly & Avg. & p-value \\
\hline $0.45 \%$ & $188^{\mathrm{a}} \pm 14$ & $192^{\mathrm{a}} \pm 17$ & $190 \pm 15$ & \multirow{3}{*}{$<0.001$} & $22.6^{\mathrm{a}} \pm 0.7$ & $23.7^{\mathrm{a}} \pm 0.4$ & $23.1 \pm 0.8$ & \multirow{3}{*}{$<0.001$} & $1,822^{\mathrm{a}} \pm 35$ & $1,863^{\mathrm{a}} \pm 46$ & $1,844 \pm 44$ & \multirow{3}{*}{$<0.001$} \\
\hline $0.60 \%$ & $237^{b} \pm 18$ & $241^{\mathrm{b}} \pm 20$ & $239 \pm 19$ & & $31.0^{\mathrm{b}} \pm 0.5$ & $32.1^{\mathrm{b}} \pm 0.8$ & $31.5 \pm 0.9$ & & $2,291^{b} \pm 52$ & $2,321^{\mathrm{b}} \pm 63$ & $2,306 \pm 58$ & \\
\hline Avg. & $213 \pm 30$ & $217 \pm 31$ & $215 \pm 30$ & & $26.8 \pm 4.4$ & $27.9 \pm 4.4$ & $27.3 \pm 4.4$ & & $2,078 \pm 249$ & $2,092 \pm 244$ & $2,085 \pm 241$ & \\
\hline $\mathrm{p}$-value & \multicolumn{2}{|c|}{0.587} & & $0.982 *$ & \multicolumn{2}{|c|}{$<0.001$} & & $0.949 *$ & \multicolumn{2}{|c|}{0.116} & & $0.786^{*}$ \\
\hline
\end{tabular}

Values indicate mean $\pm \mathrm{SD}(\mathrm{n}=6) .{ }^{1}$ True digestible threonine (AminoDat 1.1, Degussa, 1997). ${ }^{2} \mathrm{mg} / \mathrm{BW}{ }_{\mathrm{kg}}{ }^{0.67}$ per d.

${ }^{\mathrm{a}, \mathrm{b}}$ Different superscripts within a row indicate significant differences $(\mathrm{p}<0.05 ; t$-test $)$.

* p-value of interaction effect.

concentration. In this study, the TDG activities were affected by main effects (CP and Thr). In addition, the main effects were affected by an interaction effect (TDG activity: $\mathrm{p}<0.001$ in CP main effect, $\mathrm{p}=0.013$ in Thr main effect, and $p=0.016$ in interaction effect). The efficiencies of Thr utilization, concluded from N-balance studies, showed a significant $(\mathrm{p} \leq 0.001)$ reduction after supplementation with Thr at both protein levels (Table 7). In the present study, the Thr efficiencies were affected by main effects (CP and Thr) (Thr efficiency: $p=0.004$ in CP main effect, $p=0.001$ in Thr main effect, and $\mathrm{p}=0.879$ in interaction effect).

\section{Experiment 2}

A summary of data from N-balance experiments with chicks is shown in Table 2. Addition of Thr to a diet containing a CP level $(21.5 \% \quad \mathrm{CP})$ without Gly supplementation resulted in only an insignificant $(\mathrm{p}=$ 0.128 ) increase in TDG activity. On the other hand, addition

Table 3. Ingredient composition of basal diets for chicks ( $\mathrm{g} / \mathrm{kg}$ diet)

\begin{tabular}{|c|c|c|}
\hline Ingredient & $17.50 \% \mathrm{CP}$ & $21.50 \% \mathrm{CP}$ \\
\hline Soybean meal (44\% CP) & 336.00 & 448.00 \\
\hline Soybean oil & 15.00 & 15.00 \\
\hline Potato starch & 587.77 & 480.05 \\
\hline Cellulose powder & 11.00 & 7.50 \\
\hline Premix $^{1}$ & 10.00 & 10.00 \\
\hline Monocalcium phosphate & 21.50 & 18.00 \\
\hline $\mathrm{CaCO}_{3}$ & 11.90 & 12.70 \\
\hline $\mathrm{NaCl}$ & 0.80 & 0.70 \\
\hline L-Lys·HCl & 1.63 & 2.25 \\
\hline DL-Met & 4.40 & 5.80 \\
\hline Amino acid ratio ${ }^{2}$ & \multicolumn{2}{|c|}{$\begin{array}{l}\text { Lys (1):Met+Cys (0.79): } \\
\text { Thr (0.55):Trp (0.19):Arg (1.06): } \\
\text { Gly (0.60):Gly+Ser (1.29) }\end{array}$} \\
\hline
\end{tabular}

\footnotetext{
${ }^{1}$ Main ingredients per kg of premix (Co. Vilomix, Germany): $175.0 \mathrm{~g}$ calcium, 80.0 g sodium, 1,200,000 IU vitamin A, 300,000 IU vitamin $\mathrm{D}_{3}$, $3,000 \mathrm{mg}$ vitamin $\mathrm{E}, 200 \mathrm{mg}$ vitamin $\mathrm{B}_{1}, 480 \mathrm{mg}$ vitamin $\mathrm{B}_{2}, 360 \mathrm{mg}$ vitamin $\mathrm{B}_{6}, 1.5 \mathrm{mg}$ vitamin $\mathrm{B}_{12}, 300 \mathrm{mg}$ vitamin $\mathrm{K}_{3}, 5.0 \mathrm{~g}$ niacin, $900 \mathrm{mg}$ calcium-pantothenate, $90 \mathrm{mg}$ folic acid, $5 \mathrm{mg}$ biotin, $80.0 \mathrm{~g}$ choline chloride, $12.0 \mathrm{~g}$ manganese, $8.0 \mathrm{~g}$ zinc, $5.0 \mathrm{~g}$ iron, $3.0 \mathrm{~g}$ copper, $120 \mathrm{mg}$ iodine, $55 \mathrm{mg}$ cobalt, $42 \mathrm{mg}$ selenium, $10.0 \mathrm{~g}$ BHT, $12.5 \mathrm{~g}$ monensine$\mathrm{Na}$.

${ }^{2}$ Threonine was adjusted as a limiting amino acid.
}

of Thr to the diet with Gly supplementation resulted in a significant $(\mathrm{p}=0.018)$ increase in TDG activity (Table 8). Addition of Gly to a diet containing $0.45 \%$ dThr did not have a significant effect on the total activity. In addition, addition of Gly to a diet containing $0.60 \%$ dThr also did not result in a change in accumulation of Gly. Due to an increase in accumulation of aminoacetone, an elevated effect on the total TDG activity was also observed (Table 8). In the present study, the TDG activities were affected by dThr (main effect) (TDG activity: $p=0.130$ in Gly main effect, $p=0.003$ in dThr main effect, and $p=0.197$ in interaction effect). We used two levels of Gly and Thr $(0.64 \%$ Gly, $1.55 \%$ Gly+Ser [low level not near to the optimal Gly+Ser concentration]; 0.98\% Gly, 1.90\% Gly+ Ser [level near to the optimal Gly+Ser concentration]; $0.45 \%$ dThr [low level not near to the optimal Thr concentration]; $0.60 \%$ dThr [level near to the optimal Thr concentration]), respectively. The efficiency of Thr utilization did not show a significant reduction after supplementation with Gly at the level of $0.45 \% \mathrm{dThr}$. However, this efficiency was significantly $(\mathrm{p}<0.001)$ reduced after supplementation with Gly at the level of $0.60 \% \mathrm{dThr}$, indicating the end of the limiting range of Thr (Table 8). In this study, the Thr efficiencies were affected by main effects (Gly and dThr). In addition, the main effects were affected by interaction effect (Thr efficiency: $\mathrm{p}=$ 0.003 in Gly main effect, $\mathrm{p}<0.001$ in $\mathrm{dThr}$ main effect, and $\mathrm{p}=0.017$ in interaction effect).

\section{DISCUSSION}

Gly has been suggested as an essential amino acid for maximum performance of growing chicks (Corzo et al., 2004; Dean et al., 2006). Therefore, de novo synthesis of

Table 4. Analyzed contents (\%) of crude protein, glycine, serine and threonine in diets

\begin{tabular}{lrrrr}
\hline Item & $3.8 \mathrm{~g} \mathrm{Thr}^{1}$ & \multicolumn{1}{c}{$4.7 \mathrm{~g} \mathrm{Thr}$} & $3.8 \mathrm{~g} \mathrm{Thr}$ & $4.7 \mathrm{~g} \mathrm{Thr}$ \\
\hline CP & 17.50 & \multicolumn{2}{c}{21.50} \\
Gly & 0.70 & \multicolumn{2}{c}{0.94} & \multicolumn{2}{c}{2.03} \\
Gly+Ser & \multicolumn{1}{c}{1.52} & 0.86 & 1.05 \\
Thr & 0.65 & 0.79 & &
\end{tabular}


Table 5. Ingredient composition of diets for growing chicks $(\mathrm{g} / \mathrm{kg}$ diet)

\begin{tabular}{|c|c|c|c|c|}
\hline Ingredient & $\begin{array}{l}0.64 \% \text { Gly/ } \\
0.45 \% \mathrm{dThr}^{1}\end{array}$ & $\begin{array}{l}0.64 \% \text { Gly/ } \\
0.60 \% \text { dThr }\end{array}$ & $\begin{array}{l}0.98 \% \text { Gly/ } \\
0.45 \% \text { dThr }\end{array}$ & $\begin{array}{l}0.98 \% \text { Gly } / \\
0.60 \% \text { dThr }\end{array}$ \\
\hline Wheat & 400.00 & 400.00 & 400.00 & 400.00 \\
\hline Wheat gluten & 170.00 & 170.00 & 170.00 & 170.00 \\
\hline Wheat starch & 332.47 & 330.94 & 328.97 & 327.44 \\
\hline Soybean oil & 18.00 & 18.00 & 18.00 & 18.00 \\
\hline Premix $^{2}$ & 10.00 & 10.00 & 10.00 & 10.00 \\
\hline $\mathrm{CaCO}_{3}$ & 10.00 & 10.00 & 10.00 & 10.00 \\
\hline Monocalcium phosphate & 25.00 & 25.00 & 25.00 & 25.00 \\
\hline $\mathrm{NaCl}$ & 3.00 & 3.00 & 3.00 & 3.00 \\
\hline L-Lys $\cdot H C l$ & 8.70 & 8.70 & 8.70 & 8.70 \\
\hline DL-Met & 1.63 & 1.63 & 1.63 & 1.63 \\
\hline L-Gly & 0 & 0 & 3.50 & 3.50 \\
\hline L-Thr & 0 & 1.53 & 0 & 1.53 \\
\hline L-Trp & 0.35 & 0.35 & 0.35 & 0.35 \\
\hline L-Arg & 4.30 & 4.30 & 4.30 & 4.30 \\
\hline L-Ileu & 1.00 & 1.00 & 1.00 & 1.00 \\
\hline L-Val & 0.55 & 0.55 & 0.55 & 0.55 \\
\hline L-Glu & 15.00 & 15.00 & 15.00 & 15.00 \\
\hline Amino acid ratio ${ }^{3}$ & $\begin{array}{l}\text { Lys (1):Thr (0.43): } \\
\text { Gly (0.56): } \\
\text { Gly+Ser (1.34) }\end{array}$ & $\begin{array}{l}\text { Lys (1):Thr (0.56): } \\
\text { Gly (0.56): } \\
\text { Gly+Ser (1.34) }\end{array}$ & $\begin{array}{l}\text { Lys (1):Thr (0.43): } \\
\text { Gly (0.86): } \\
\text { Gly+Ser (1.64) }\end{array}$ & $\begin{array}{l}\text { Lys (1):Thr (0.56): } \\
\text { Gly }(0.86) \text { : } \\
\text { Gly+Ser (1.64) }\end{array}$ \\
\hline $\mathrm{ME}_{\mathrm{N}}(\mathrm{MJ} / \mathrm{kg} \mathrm{DM})$ & 14.89 & 14.89 & 14.89 & 14.89 \\
\hline
\end{tabular}

${ }^{1}$ True digestible threonine (AminoDat 1.1, Degussa, 1997).

${ }^{2}$ Main ingredients per kg of premix (Co. Vilomix, Germany): $175.0 \mathrm{~g}$ calcium, $80.0 \mathrm{~g}$ sodium, 1,200,000 IU vitamin A, 300,000 IU vitamin D , 3,000 mg vitamin E, $200 \mathrm{mg}$ vitamin $\mathrm{B}_{1}, 480 \mathrm{mg}$ vitamin $\mathrm{B}_{2}, 360 \mathrm{mg}$ vitamin $\mathrm{B}_{6}, 1.5 \mathrm{mg}$ vitamin $\mathrm{B}_{12}, 300 \mathrm{mg}$ vitamin $\mathrm{K}_{3}, 5.0 \mathrm{~g}$ niacin, $900 \mathrm{mg}$ calciumpantothenate, $90 \mathrm{mg}$ folic acid, $5 \mathrm{mg}$ biotin, $80.0 \mathrm{~g}$ choline chloride, $12.0 \mathrm{~g}$ manganese, $8.0 \mathrm{~g}$ zinc, $5.0 \mathrm{~g}$ iron, $3.0 \mathrm{~g}$ copper, $120 \mathrm{mg}$ iodine, $55 \mathrm{mg}$ cobalt, $42 \mathrm{mg}$ selenium, $10.0 \mathrm{~g}$ BHT, $12.5 \mathrm{~g}$ monensine-Na.

${ }^{3}$ Threonine was adjusted as a limiting amino acid; Lys (1):Met/Cys (0.79):Trp (0.19):Arg (1.05) in the diets.

Gly is of importance in amino acid metabolism. In this study, we investigated the relationship between $\mathrm{Thr}$ efficiency and TDG activity as an indicator of Thr oxidation on chicks fed with graded levels of Gly, Thr, and protein.

An increase of dietary Thr supply (from 0.65 [3.8 g Thr/100 g of CP] to $0.79 \%$ [4.7 g Thr/100 g of CP] Thr) had no significant $(p>0.05)$ effect on the TDG activity of chick liver in diets containing $17.5 \% \mathrm{CP}$. This finding is supported by a report by Davis and Austic (1997) in chicks indicating that hepatic TDG activity was outstandingly affected by the level of protein in the diet. On the other hand, a significant $(p=0.014)$ increase in TDG activity in the liver of growing chicks was shown only after elevation of the dietary supply of Thr from $0.86(3.8 \mathrm{~g} \mathrm{Thr} / 100 \mathrm{~g}$ of $\mathrm{CP})$ to $1.05 \% \mathrm{Thr}(4.7 \mathrm{~g} \mathrm{Thr} / 100 \mathrm{~g}$ of $\mathrm{CP})$ in diets containing $21.5 \% \mathrm{CP}$. Our results are in general agreement with results reported by Le Floc'h et al. (1994, 1996) indicating that hepatic TDG activity was dependent on the level of Thr in the diet of growing pigs. In the TDG activity, main effects (CP and Thr) are considered to be affected by interaction effect. Certainly, a moderate excess of Thr by supplementation with $\mathrm{Thr}$ in the low protein diet $(17.5 \%$ $\mathrm{CP}$ ) was not significantly oxidized through the Thr dehydrogenase pathway in chick liver, but Thr may also be degraded by Thr dehydratase (Moghaddam et al., 2011). In the present study, Thr efficiencies indicated a significant $(\mathrm{p} \leq 0.001)$ decrease after Thr-addition at protein levels ( $17.5 \%$ and $21.5 \% \mathrm{CP}$ ). Collectively, the Thr efficiencies are considered to be affected by main effects (CP and Thr). The lower the value of Thr efficiency $\left(b c^{-1}\right)$, the nearer the Thr level of the diet is to the optimal Thr concentration (Lee et al., 2011). Therefore, the Thr level of diet (17.5\% CP $4.7 \mathrm{~g} \mathrm{Thr} / 100 \mathrm{~g} \mathrm{CP})$ is thought to be the nearest of all groups to the optimal $\mathrm{Thr}$ concentration.

Addition of Thr (from $0.45 \%$ to $0.60 \% \mathrm{dThr}$ ) in a diet without addition of Gly $(0.64 \%$ Gly, $1.55 \%$ Gly+Ser $)$ showed an insignificant $(\mathrm{p}=0.128$ for TDG; $\mathrm{p}=0.053$ for Gly) increase in TDG activity and accumulation of Gly. The

Table 6. Analyzed contents (\%) of glycine, serine and threonine in $21.5 \% \mathrm{CP}$ diets

\begin{tabular}{lcccc}
\hline Item & $0.64 \%$ Gly $/$ & $0.64 \%$ Gly $/$ & $0.98 \%$ Gly $/$ & $0.98 \%$ Gly/ \\
& $0.45 \% \mathrm{dThr}^{1}$ & $0.60 \% \mathrm{dThr}^{1}$ & $0.45 \% \mathrm{dThr}^{2}$ & $0.60 \% \mathrm{dThr}^{2}$ \\
\hline Gly & \multicolumn{2}{c}{0.64} & \multicolumn{2}{c}{0.98} \\
Gly+Ser & \multicolumn{2}{c}{1.55} & 0.90 & 1.90 \\
dThr & 0.45 & 0.60 & 0.45 & 0.60
\end{tabular}

${ }^{1}$ Diet without Gly addition. ${ }^{2}$ Diet with Gly addition. 
Table 7. Effects of threonine and protein levels of the diets on liver TDG activity and threonine efficiency in chicks

\begin{tabular}{|c|c|c|c|c|c|c|c|c|c|c|c|c|c|c|c|c|c|c|c|c|}
\hline \multirow{3}{*}{ Thr } & \multirow{2}{*}{\multicolumn{4}{|c|}{ Thr efficiency $\left(b c^{-1}\right)^{1}$}} & \multirow{2}{*}{\multicolumn{4}{|c|}{ Mean liver weight }} & \multicolumn{12}{|c|}{ TDG-activity (nmol/30 min/mg protein) } \\
\hline & & & & & & & & & \multicolumn{4}{|c|}{ Aminoacetone } & \multicolumn{4}{|c|}{ Glycine } & \multicolumn{4}{|c|}{ Total activity } \\
\hline & $\begin{array}{c}17.5 \% \\
\mathrm{CP}\end{array}$ & $\begin{array}{c}21.5 \% \\
\text { CP }\end{array}$ & Avg. & p-value & $\begin{array}{c}17.5 \% \\
\mathrm{CP}\end{array}$ & $\begin{array}{c}21.5 \% \\
\mathrm{CP}\end{array}$ & Avg. & p-value & $\begin{array}{c}17.5 \% \\
\mathrm{CP}\end{array}$ & $\begin{array}{c}21.5 \% \\
\text { CP }\end{array}$ & Avg. & p-value & $\begin{array}{c}17.5 \% \\
\mathrm{CP}\end{array}$ & $\begin{array}{c}21.5 \% \\
\mathrm{CP}\end{array}$ & Avg. & $\mathrm{p}$-value & $\begin{array}{c}17.5 \% \\
\text { CP }\end{array}$ & $\begin{array}{c}21.5 \% \\
\mathrm{CP}\end{array}$ & Avg. & $\mathrm{p}$-value \\
\hline $\begin{array}{l}3.8 \mathrm{~g} \\
/ 100 \mathrm{~g} \mathrm{CP}\end{array}$ & $\begin{array}{l}111^{\mathrm{a}} \\
\pm 3\end{array}$ & $\begin{array}{l}120^{\circ} \\
\pm 10\end{array}$ & $\begin{array}{r}115.50 \\
\pm 8.04\end{array}$ & \multirow{2}{*}{0.001} & $\begin{array}{l}24.20^{\mathrm{c}} \\
\pm 3.47\end{array}$ & $\begin{array}{l}18.30^{\mathrm{b}} \\
\pm 1.84\end{array}$ & $\begin{array}{l}21.25 \\
\pm 4.06\end{array}$ & \multirow{2}{*}{$<0.001$} & $\begin{array}{r}2.33^{\mathrm{a}} \\
\pm 1.33\end{array}$ & $\begin{array}{c}2.84^{\mathrm{a}} \\
\pm 1.29\end{array}$ & $\begin{array}{r}2.58 \\
\pm 1.27\end{array}$ & \multirow[b]{2}{*}{0.013} & $\begin{array}{r}1.45^{a} \\
\pm 0.36\end{array}$ & $\begin{array}{r}2.86^{\mathrm{b}} \\
\pm 0.98\end{array}$ & $\begin{array}{r}2.16 \\
\pm 1.02\end{array}$ & \multirow[b]{2}{*}{0.076} & $\begin{array}{r}3.78^{\mathrm{a}} \\
\pm 1.33\end{array}$ & $\begin{array}{r}5.71^{\mathrm{a}} \\
\pm 2.01\end{array}$ & $\begin{array}{r}4.74 \\
\pm 1.91\end{array}$ & \multirow[b]{2}{*}{0.013} \\
\hline $\begin{array}{l}4.7 \mathrm{~g} \\
/ 100 \mathrm{~g} \mathrm{CP}\end{array}$ & $\begin{array}{c}100^{\mathrm{b}} \\
\pm 3\end{array}$ & $\begin{array}{c}110^{\mathrm{a}} \\
\pm 8\end{array}$ & $\begin{array}{r}104.92 \\
\pm 7.56\end{array}$ & & $\begin{array}{l}15.70^{\mathrm{a}} \\
\pm 1.30\end{array}$ & $\begin{array}{l}13.10^{\mathrm{a}} \\
\pm 1.38\end{array}$ & $\begin{array}{l}14.28 \\
\pm 1.86\end{array}$ & & $\begin{array}{r}2.42^{\mathrm{a}} \\
\pm 1.19\end{array}$ & $\begin{array}{c}5.71^{\mathrm{b}} \\
\pm 1.40\end{array}$ & $\begin{array}{r}3.92 \\
\pm 2.11\end{array}$ & & $\begin{array}{r}1.45^{\mathrm{a}} \\
\pm 0.80\end{array}$ & $\begin{array}{r}4.62^{\mathrm{b}} \\
\pm 1.94\end{array}$ & $\begin{array}{r}2.89 \\
\pm 2.14\end{array}$ & & $\begin{array}{c}3.87^{\mathrm{a}} \\
\pm 1.65\end{array}$ & $\begin{array}{l}10.33^{\mathrm{b}} \\
\pm 3.05\end{array}$ & $\begin{array}{r}6.81 \\
\pm 4.06\end{array}$ & \\
\hline Avg. & $\begin{array}{r}105.83 \\
\pm 6.31\end{array}$ & $\begin{array}{l}114.58 \\
\pm 10.07\end{array}$ & $\begin{array}{r}110.21 \\
\pm 9.35\end{array}$ & & $\begin{array}{l}20.33 \\
\pm 5.14\end{array}$ & $\begin{array}{r}15.70 \\
\pm 3.13\end{array}$ & $\begin{array}{l}17.92 \\
\pm 4.74\end{array}$ & & $\begin{array}{r}2.37 \\
\pm 1.20\end{array}$ & $\begin{array}{r}4.15 \\
\pm 1.96\end{array}$ & $\begin{array}{r}3.22 \\
\pm 1.82\end{array}$ & & $\begin{array}{r}1.45 \\
\pm 0.59\end{array}$ & $\begin{array}{r}3.66 \\
\pm 1.68\end{array}$ & $\begin{array}{r}2.51 \\
\pm 1.65\end{array}$ & & $\begin{array}{r}3.83 \\
\pm 1.43\end{array}$ & $\begin{array}{r}7.81 \\
\pm 3.40\end{array}$ & $\begin{array}{r}5.73 \\
\pm 3.23\end{array}$ & \\
\hline p-value & \multicolumn{2}{|c|}{0.004} & & $0.879 *$ & \multicolumn{2}{|c|}{$<0.001$} & & $0.091 *$ & \multicolumn{2}{|c|}{0.002} & & $0.019^{*}$ & \multicolumn{2}{|c|}{$<0.001$} & & $0.075^{*}$ & \multicolumn{2}{|c|}{$<0.001$} & & $0.016^{*}$ \\
\hline
\end{tabular}

Values indicate mean \pm SD $(n=6) .{ }^{1}$ Calculated from N-balance data, exponential N-utilization model.

${ }^{\mathrm{a}, \mathrm{b}, \mathrm{c}}$ Different superscripts within a row indicate significant differences $(\mathrm{p}<0.05 ; t$-test).

* p-value of interaction effect.

increase of TDG activity by elevating the Thr content (from $0.45 \%$ to $0.60 \% \mathrm{dThr}$ ) in a diet without addition of Gly gives an indication of the Thr limiting range. This finding was confirmed by a result showing no significant $(p>0.05)$ decrease in value of the efficiency of Thr utilization. On the other hand, addition of $\mathrm{Thr}$ (from $0.45 \%$ to $0.60 \% \mathrm{dThr}$ ) to the diet with addition of Gly $(0.98 \%$ Gly, $1.90 \%$ Gly+Ser $)$ resulted in a significant $(p=0.018)$ increase in total TDG activity. This significantly increased total TDG activity presumably indicates the end of the Thr limiting range. Accordingly, there was a significantly $(p=0.001)$ lower efficiency of Thr utilization. These results are in general agreement with findings reported by Lee et al. (2011) in chicks showing that TDG activity in the liver was elevated by the diet containing $22.5 \% \mathrm{CP}(0.60 \% \mathrm{dThr})$ and the efficiency of Thr utilization was simultaneously decreased. Addition of Gly to a diet containing $0.45 \% \mathrm{dThr}$ did not have a significant effect on total TDG activity and accumulation of Gly. In addition, the efficiency of Thr utilization was not significantly reduced after addition of Gly at the level of $0.45 \% \mathrm{dThr}$. These findings are supported by results reported by Le Floc'h et al. (1994, 1996) in pigs indicating that the hepatic TDG activity was outstandingly affected by the Thr level in the diet. In addition, addition of Gly to a diet containing $0.60 \% \mathrm{dThr}$ did not result in a change in accumulation of Gly. Due to an increase in accumulation of aminoacetone, an elevated effect on total TDG activity was also observed. This finding is in general agreement with reports from Davis and Austic (1994) and Le Floc'h et al. (1994) indicating that hepatic TDG was also stimulated by addition of different amino acids. In the present study, the TDG activities are considered to be affected only by dThr (main effect). In addition, the efficiency of Thr utilization showed a significant $(p<0.001)$ reduction after addition of Gly at the level of $0.60 \% \mathrm{dThr}$, indicating the end of the limiting range of Thr. This result demonstrates that the efficiency of Thr utilization was favorably affected by addition of Gly. This finding is also supported by a report by Davis and Austic (1997) in chicks showing that TDG activity is influenced by protein level or other amino acids more than by Thr. In the previous study (Lee et al., 2011), we found that the efficiency of Thr utilization is simultaneously decreased by enhanced degradation of Thr through TDG. In the Thr efficiency, main effects (Gly and dThr) are considered to be affected by interaction effect. Taken together, the Thr level of diet $(0.98 \%$ Gly to $0.60 \% \mathrm{dThr})$ is thought to be the nearest of all groups to the optimal Thr concentration. In this study, no metabolic requirement of Gly through the TDG pathway was observed with almost the same accumulation of Gly and a slight increase in TDG activity by addition of Gly. This finding is not consistent with suggestion from Le Floc'h et al. (1994) that the de novo Gly synthesis from Thr might partly cover the metabolic requirements for Gly. The TDG activity in the liver of rat and growing chick has an indicator function for the dietary

Table 8. Effects of glycine and threonine levels of the diet on liver TDG activity and threonine efficiency in growing chicks

\begin{tabular}{|c|c|c|c|c|c|c|c|c|c|c|c|c|c|c|c|c|c|c|c|c|}
\hline \multirow{3}{*}{$\mathrm{dThr}{ }^{1}$} & \multirow{2}{*}{\multicolumn{4}{|c|}{ Thr efficiency $\left(\mathrm{bc}^{-1}\right)^{2}$}} & \multirow{2}{*}{\multicolumn{4}{|c|}{ Mean liver weight }} & \multicolumn{12}{|c|}{ TDG-activity (nmol/30 min/mg protein) } \\
\hline & & & & & & & & & \multicolumn{4}{|c|}{ Aminoacetone } & \multicolumn{4}{|c|}{ Glycine } & \multicolumn{4}{|c|}{ Total activity } \\
\hline & $\begin{array}{c}0.64 \% \\
\text { Gly }\end{array}$ & $\begin{array}{c}0.98 \% \\
\text { Gly }\end{array}$ & Avg. & p-value & $\begin{array}{c}0.64 \% \\
\text { Gly }\end{array}$ & $\begin{array}{c}0.98 \% \\
\text { Gly }\end{array}$ & Avg. & $\mathrm{p}$-value & $\begin{array}{c}0.64 \% \\
\text { Gly }\end{array}$ & $\begin{array}{c}0.98 \% \\
\text { Gly }\end{array}$ & Avg. & $\mathrm{p}$-value & $\begin{array}{c}0.64 \% \\
\text { Gly }\end{array}$ & $\begin{array}{c}0.98 \% \\
\text { Gly }\end{array}$ & Avg. & p-value & $\begin{array}{c}0.64 \% \\
\text { Gly }\end{array}$ & $\begin{array}{c}0.98 \% \\
\text { Gly }\end{array}$ & Avg. & $\mathrm{p}$-value \\
\hline $0.45 \%$ & $120^{\mathrm{a}}$ & $119^{\mathrm{a}}$ & 119 & \multirow{4}{*}{$<0.001$} & $7.10^{\mathrm{a}}$ & $6.30^{\mathrm{a}}$ & 6.70 & \multirow{4}{*}{$<0.001$} & $3.55^{\mathrm{a}}$ & $3.52^{\mathrm{a}}$ & 3.54 & \multirow{4}{*}{0.011} & $3.24^{\mathrm{a}}$ & $3.62^{\mathrm{a}}$ & 3.43 & & $6.79^{\mathrm{a}}$ & $7.14^{\mathrm{a}}$ & 6.97 & \multirow{4}{*}{0.003} \\
\hline \multirow{3}{*}{$0.60 \%$} & \pm 5 & \pm 4 & \pm 4 & & \pm 0.94 & \pm 0.57 & \pm 0.85 & & \pm 1.77 & \pm 1.21 & \pm 1.44 & & \pm 1.21 & \pm 1.83 & \pm 1.49 & \multirow{3}{*}{0.024} & \pm 2.43 & \pm 2.93 & \pm 2.57 & \\
\hline & $117^{\mathrm{a}}$ & $108^{\mathrm{b}}$ & 112 & & $11.20^{\mathrm{b}}$ & $14.40^{\mathrm{c}}$ & 12.65 & & $4.24^{\mathrm{ab}}$ & $8.77^{\mathrm{b}}$ & 6.30 & & $5.40^{\mathrm{a}}$ & $5.01^{\mathrm{a}}$ & 5.22 & & $9.64^{\mathrm{ab}}$ & $13.78^{\mathrm{b}}$ & 11.52 & \\
\hline & \pm 3 & \pm 3 & \pm 6 & & \pm 1.08 & \pm 0.93 & \pm 1.93 & & \pm 1.44 & \pm 4.71 & \pm 3.94 & & \pm 2.09 & \pm 1.64 & \pm 1.82 & & \pm 3.44 & \pm 4.66 & \pm 4.39 & \\
\hline \multirow[t]{2}{*}{ Avg. } & 119 & 113 & 116 & & 9.15 & 9.98 & 9.55 & & 3.90 & 5.91 & 4.86 & & 4.32 & 4.25 & 4.29 & & 8.22 & 10.16 & 9.15 & \\
\hline & \pm 4 & \pm 7 & \pm 6 & & \pm 2.35 & \pm 4.29 & \pm 3.36 & & \pm 1.58 & \pm 4.14 & \pm 3.18 & & \pm 1.98 & \pm 1.81 & \pm 1.86 & & \pm 3.21 & \pm 5.00 & \pm 4.18 & \\
\hline p-value & \multicolumn{2}{|c|}{0.003} & & $0.017^{*}$ & \multicolumn{2}{|c|}{0.005} & & $<0.001^{*}$ & \multicolumn{2}{|c|}{0.048} & & $0.045^{*}$ & \multicolumn{2}{|c|}{0.993} & & $0.603^{*}$ & \multicolumn{2}{|c|}{0.130} & & $0.197 *$ \\
\hline
\end{tabular}

Values indicate mean $\pm \mathrm{SD}(\mathrm{n}=6)$.

${ }^{1}$ True digestible threonine (AminoDat 1.1, Degussa, 1997). ${ }^{2}$ Calculated from N-balance data, exponential N-utilization model.

a,b,c Different superscripts within a row indicate significant differences $(\mathrm{p}<0.05 ; t$-test $)$.

* p-value of interaction effect. 
supply of Thr and the efficiency of Thr utilization derived from N-balance data and calculated within the applied exponential $\mathrm{N}$-utilization model is generally an indicator of the limiting range of a dietary essential amino acid (Liebert, 1995; Thong and Liebert, 2004; Liebert, 2008; Wecke and Liebert, 2010; Lee et al., 2011). However, the effects on the efficiency of $\mathrm{Thr}$ utilization $\left(\mathrm{bc}^{-1}\right)$ are not completely consistent with results from $\mathrm{Thr}$ oxidation in the liver of rat and chick (Lee et al., 2011). Therefore, further studies are required to elucidate the relationship between Thr efficiency and Thr oxidation.

In conclusion, we demonstrated that TDG was stimulated not only by addition of Thr and protein to the diet, but also by addition of Gly and efficiency of Thr utilization was favorably affected by addition of Gly at the level near to the optimal Thr concentration. In addition, no metabolic requirement of Gly through the TDG pathway was observed with almost the same accumulation of Gly and a slight increase in TDG activity by addition of Gly. Thus, our findings suggest that determination of TDG activity and parameter of efficiency of Thr utilization may be useful for evaluation of dietary Thr level.

\section{ACKNOWLEDGEMENTS}

This work was supported by a grant of the New Growth Engine Industry Division, Busan Metropolitan City, Korea, and by the National Research Foundation of Korea (NRF) Grant funded by the Korean Government (MSIP) (No. 2012-0009400).

\section{REFERENCES}

Asai, S., H. Nakamura, W. Okada, and M. Yamada. 1995. Synthesis of hippuric acid with inverse phase transfer catalyst in a heterogeneous liquid-liquid reaction system. Chem. Eng. Sci. 50:943-949.

Ayaşan, T., F. Okan, and H. Hizli. 2009. Threonine requirement of broilers from 22 to 42 days. Int. J. Poult. Sci. 8:862-865.

Baker, D. H. and Y. Han. 1994. Ideal amino acid profile for chicks during the first three weeks posthatching. Poult. Sci. 73:14411447.

Baylan, M., S. Canogullari, T. Ayasan, and A. Sahin. 2006. Dietary threonine supplementation for improving growth performance and edible carcass parts in Japanese quails, Coturnix coturnix japonica. Int. J. Poult. Sci. 5:635-638.

Corzo, A., M. T. Kidd, D. J. Burnham, and B. J. Kerr. 2004. Dietary glycine needs of broiler chicks. Poult. Sci. 83:13821384.

Corzo, A., M. T. Kidd, W. A. Dozier, and B. J. Kerr. 2009. Dietary glycine and threonine interactive effects in broilers. J. Appl. Poult. Res. 18:79-84.

Davis, A. J. and R. E. Austic. 1994. Dietary threonine imbalance alters threonine dehydrogenase activity in isolated hepatic mitochondria of chicks and rats. J. Nutr. 124:1667 -1677.
Davis, A. J. and R. E. Austic. 1997. Dietary protein and amino acid levels alter threonine dehydrogenase activity in hepatic mitochondria of Gallus domesticus. J. Nutr. 127:738-744.

Dean, D. W., T. D. Bidner, and L. L. Southern. 2006. Glycine supplementation to low crude protein, amino acidsupplemented diets supports optimal performance of broiler chicks. Poult. Sci. 85:288-296.

Furuya, S. 2008. An essential role for de novo biosynthesis of Lserine in CNS development. Asia Pac. J. Clin. Nutr. 17:312315.

Lamers, Y., J. Williamson, L. R. Gilbert, P. W. Stacpoole, and J. F. Gregory. 2007. Glycine turnover and decarboxylation rate quantified in healthy men and women using primed, constant infusions of [1,2-(13)C2]glycine and [(2)H3]leucine. J. Nutr. 137:2647-2652.

Lee, C. W., Y. J. Oh, Y. S. Son, and W. G. An. 2011. Effects of dietary protein and threonine supply on in vitro liver threonine dehydrogenase activity and threonine efficiency in rat and chicken. Asian-Aust. J. Anim. Sci. 24:1417-1424.

Le Floc'h, N., B. Sève, and Y. Henry. 1994. The addition of glutamic acid or protein to a threonine-deficient diet differentially affects growth performance and threonine dehydrogenase activity in fattening pigs. J. Nutr. 124:19871995.

Le Floc'h, N., C. Obled, and B. Sève. 1996. In vivo threonine oxidation in growing pigs fed on diets with graded levels of threonine. Br. J. Nutr. 75:825-837.

Liebert, F. 1995. Methodische untersuchungen zur beurteilung von lysinverwertungskennzahlen von schweinen nach extremen veränderungen von proteinmenge und -zusammensetzung. Arch. Anim. Nutr. 48:319-327.

Liebert, F. 2008. Modelling of protein metabolism yields amino acid requirements dependent on dietary amino acid efficiency, growth response, genotype and age of growing chicken. Avian Biol. Res. 1:101-110.

Moghaddam, H. S., H. N. Moghaddam, H. Kermanshahi, A. H. Mosavi, and A. Raji. 2011. The effect of threonine on mucin2 gene expression, intestinal histology and performance of broiler chicken. Ital. J. Anim. Sci. 10:e14.

NRC. 1994. Nutrient requirements of poultry. 9th rev. ed. Natl. Acad. Press, Washington, DC.

Osanai, M. and M. Okudaira. 2001. Syntheses of glycine and Lserine by their interconversion in the posterior silkgland of the silkworm, Bombyx mori. Amino Acids 20:113-121.

Rimbach, M. and F. Liebert. 2000. Ergebnisse zum altersabhängigen Threoninbedarf aktueller Broilergenotypen. Proc. Soc. Nutr. Physiol. 9:106.

Samadi and F. Liebert. 2006. Estimation of nitrogen maintenance requirement and potential for nitrogen deposition in fast growing chickens depending on age and sex. Poult. Sci. 85:1421-1429.

Sartori, A., H. M. Garay-Malpartida, M. F. Forni, R. I. Schumacher, F. Dutra, M. C. Sogayar, and E. J. H. Bechara. 2008. Aminoacetone, a putative endogenous source of methylglyoxal, causes oxidative stress and death to insulinproducing RINm5f cells. Chem. Res. Toxicol. 21:1841-1850.

Schutte, J. B., W. Smink, and M. Pack. 1997. Requirement of young broiler chicks for glycine and serine. Arch. Geflugelkd. 61:43-47. 
SPSS 2005. Statistical package for social sciences, SPSS 14.0 for Windows. Statistical package for social sciences. SPSS Inc., Chicago, IL, USA.

te Braake, F., H. Schierbeek, K. de Groof, A. Vermes, M. Longini, G. Buonocore, and J. B. van Goudoever. 2008. Glutathione synthesis rates after amino acid administration directly after birth in preterm infants. Am. J. Clin. Nutr. 88:333-339.

Thong, H. T. and F. Liebert. 2004. Potential for protein deposition and threonine requirement of modern genotype barrows fed graded levels of protein with threonine as limiting amino acid. J. Anim. Physiol. Anim. Nutr. (Berl) 88:196-203.

Waguespack, A. M. 2005. Low crude protein, amino acidsupplemented diets, and the glycine requirement in low crude protein diets for broilers. A thesis. http://etd.lsu.edu/docs /available/etd-11142007-170943/unrestricted/AMWThesisab solutefinalversion.pdf.
Waguespack, A. M., S. Powell, T. D. Bidner, and L. L. Southern. 2009. The glycine plus serine requirement of broiler chicks fed low-crude protein, corn-soybean meal diets. J. Appl. Poult. Res. 18:761-765.

Waldroup, P. W., Q. Jiang, and C. A. Fritts. 2005. Effects of glycine and threonine supplementation on performance of broiler chicks fed diets low in crude protein. Int. J. Poult. Sci. 4:250-257.

Wecke, C. and F. Liebert. 2010. Optimal dietary lysine to threonine ratio in pigs (30-110 kg BW) derived from observed dietary amino acid efficiency. J. Anim. Physiol. Anim. Nutr. (Berl) 94:e277-285.

Wyss, M. and R. Kaddurah-Daouk. 2000. Cretine and creatinine metabolism. Physiol. Rev. 8:1107-1213.

Yuan, J. H. and R. E. Austic. 2001. The effect of dietary protein level on threonine dehydrogenase activity in chickens. Poult. Sci. 80:1353-1356. 